\title{
A conceptual framework for the assessment of multiple functions of agro-ecosystems: A case study of Trás-os-Montes olive groves
}

\author{
Luuk Fleskens $^{\mathrm{a}, *}$, Filomena Duarte ${ }^{\mathrm{b}}$, Irmgard Eicher ${ }^{\mathrm{a}, \mathrm{c}}$ \\ ${ }^{a}$ Wageningen University, Erosion and Soil and Water Conservation Group, P.O. Box 47, 6700 AA Wageningen, The Netherlands \\ ${ }^{\mathrm{b}}$ Instituto Superior de Agronomia, Departamento de Economia Agrária e Sociología Rural, Tapada da Ajuda, 1349-017 Lisbon, Portugal \\ ${ }^{\mathrm{c}}$ Haspelstraße 6, 82276 Adelshofen, Ortsteil Luttenwang, Germany
}

Keywords:

Multifunctionality

Agro-ecosystem

Olive orchards

Stakeholder perspectives

Scales of assessment

\begin{abstract}
A B S T R A C T
Multifunctionality in agriculture has received a lot of attention the last decade from researchers and policy-makers alike, perhaps most notably evidenced by the important changes made to the EU's Common Agricultural Policy. While the concept has been embraced by environmentalists envisioning positive impulses for decoupling and a range of local stakeholders recognizing implicit marketing opportunities involved, it has also been criticized as a mere argument in favour of disguised protectionism. Problematic in this discussion is the lack of an operationalising framework for the assessment of multiple functions. In this paper, we discuss such a framework and the role it can play in the decisionmaking process. Focusing on a case study about olive farming on sloping and mountainous land in northeastern Portugal, the contribution discusses methods for studying multiple functions of agroecosystems. While function assessment is presented from a research perspective, its relevance for stakeholders is also stressed here. By using the metaphor of a house, the method could appeal to a wide range of actors. In the case study, we conclude that olive groves on sloping and mountainous land particularly fall short in supplying ecological functions. They do however contribute significantly to the local economy, generate employment and perform an important role in maintaining the cultural landscape and identity, and are thus vital to regional development and to stop outmigration of the population. Policy-makers could use the function assessment tool to design effective cross-compliance rules and relevant agro-environmental measures to reinforce ecological and social functions, and to communicate ideas to other stakeholders. As such, it provides an extension of public debate and can reinforce decision-making by visualizing trends, development alternatives or scenarios. The role of research in this method is to facilitate dialogue between stakeholder groups and to feed the process with relevant indicators.
\end{abstract}

(c) 2008 Elsevier Ltd. All rights reserved.

\section{Introduction}

The OECD study "Multifunctionality; towards an analytical framework" (OECD, 2001) presents a thorough analysis of the multifunctionality concept from an economist's perspective. Afterwards, a number of publications dealing with theoretical economic (Randall, 2002; Harvey, 2003), ethical (Paarlberg et al., 2002; Vatn, 2002) or sociological studies (Knickel and Renting, 2000; Knickel, 2001) have appeared on the topic, and more recently a review integrating concepts from different disciplines (McCarthy, 2005). An apparent lacuna in the literature is a study operationalising the concept (Brandt and Vejre, 2004). Moreover, the absence

\footnotetext{
* Corresponding author.

E-mail address: luukcarla@gmail.com (L. Fleskens).
}

of studies advocating assessment of multiple functions in the decision-making process is surprising. Hall et al. (2004) come to a similar conclusion with regard to the analysis of societal wishes for the management of the countryside. A major effort to achieve informed decision-making on management of the environment is being undertaken by a global coalition of scientists in the Millennium Ecosystem Assessment (MEA, 2005).

The recognition of multiple functions of land use is in itself not a new issue. Perhaps not surprisingly, the densely populated Netherlands has had a scientific discussion about those functions dating back to the late 1960s, see, e.g. van der Ploeg and Vlijm (1978). However, the arrival of the term in policy documents in 1990s has added a dimension in that it has become linked to the discussion of paying third parties - farmers - for public services and goods that they produce alongside food and fibre (e.g. Potter and Burney, 2002). In this contemporary sense of the word, it seems 
to have gradually evolved from earlier concepts as 'pluri-activity' dating back to 1980s (e.g. Fuller, 1990; Reis et al., 1990) and 'postproductivism' (e.g. Marsden et al., 1993, cited in Wilson, 2001). Evans et al. (2002) quite rightly criticise the use of the latter term, and whether or not the same line of reasoning was followed by scholars introducing the concept of multifunctionality, sure is that the shift of paradigm has followed some 'post-shockwave' behaviour in which initial excitement over other functions overtaking agriculture's productive functions has been matured into a neutral word not issuing any value statement as to what extent other functions may gain importance.

However, the neutrality of agricultural multifunctionality has been challenged by Wilson (2007), arguing that it should be used as a normative concept both describing and explaining rural (agricultural) change. He defines the multifunctional agricultural space as a paradigm for decision-making along a productivist/non-productivist spectrum, with notions of weak and strong multifunctionality characterizing the extremes, and an intermediate multifunctionality in the middle. While we will concentrate on multifunctional agriculture, a rural space could develop multifunctionality beyond agriculture, i.e. a complete loss of the productive function of agriculture.

Weak and strong multifunctionality were also distinguished by Hollander (2004), with the 'weak' end of the spectrum representing an ill-conceived protectionalist policy-driven concept. The OECD (2001) definition of multifunctionality as "a characteristic, either present or not, of agriculture (or any other type of economic activity) whereby products are - either intentionally or not - co-produced", has been criticized as too narrowly economistic and not capable of addressing what multifunctionality is about (Wilson, 2007). The multiple functions of agriculture include products (goods or services, marketable or public) but also less tangible elements of rural development, such as social inclusion, cultural heritage and landscape value, which may not be easily disentangled. Contested though the definition of multifunctionality may be, there is general consensus that where applied it should be firmly area-based (Holmes, 2002, 2006; Wilson, 2007).

Several classifications of the various functions of (agro-) ecosystems have been made, roughly taking two different approaches:

(i) Functions are defined as ecosystem functions with humans (potentially) attaching values to functions (de Groot, 1992; de Groot et al., 2002). This approach is followed by the Millennium Ecosystem Assessment (MEA, 2005), with similar applications relating to landscapes (not necessarily agricultural ones, Brandt and Vejre, 2004) and an Andean 'socioecosystem' (Rodriguez et al., 2006). This approach evolves from an ecologist's perspective emphasizing the entity of the natural environment (van der Maarel and Dauvellier, 1978).

(ii) Functions are defined taking a broader, human-centred perspective including types of capital other than natural capital (e.g. Bosshard, 2000; von Wiren-Lehr, 2001; Gómez-Sal et al., 2003). The role of the natural ecosystem in this approach can ultimately be reduced to satisfying the demands from society (for an early account, see Bouma and van der Ploeg, 1975).

Combinations of the above approaches are also possible, by taking an hierarchical approach with ecosystem functions at the basis and other functions as 'derived' functions. For example, van Cauwenbergh et al. (2007) present a hierarchical framework for assessing the sustainability of agricultural systems based on de Groot's ecosystem functions but including functions in economic and social domains.
Function assessment as it is understood here is a method to study the multifunctionality of (parts of) agro-ecosystems, in this case Sloping and Mountainous Olive Plantation Systems (SMOPS) in southern Europe. Agro-ecosystems are ecosystems modified by human beings to produce agricultural products, thereby acquiring a socio-economic dimension (Conway, 1987). SMOPS, as (major components of) agro-ecosystems, have some specific characteristics: they often originate from Roman times and developed on land where other crops would not grow and irrigation was not feasible. In order to adapt to the peculiar Mediterranean climatic conditions a range of soil and water conservation measures has been practiced (Stroosnijder et al., 2008). As SMOPS cannot compete with better endowed plantations in lowland regions in the narrowly productive sense, the concept of multifunctionality is particularly relevant for their future development.

An important characteristic of different types of functions is that by putting more emphasis on one function, other functions can be affected in variable ways. A (participatory) planning process aims to arrive at a decision about what mix of functions to pursue. Crucial in this process is that different stakeholders may value functions differently and that the importance of functions varies across scales of analysis (Hein et al., 2006). Hence, to assess agro-ecosystem functions, indicators are needed that are (1) informative about changes in important processes; (2) sensitive to changes; (3) appropriate at temporal and spatial scales considered; (4) wellunderstood and based on generally accepted conceptual models; (5) relatively undemanding in terms of data collection; (6) preferentially reliant on existing monitoring systems; and (7) easily understandable by policy-makers (MEA, 2005, p. 50).

Indicators work best if they serve a well-defined purpose. If this purpose concerns sustainability evaluation, a holistic framework is required (López-Ridaura et al., 2005; van Cauwenbergh et al., 2007). If this is assessing multifunctionality, a selection of indicators that capture the importance of key functions (those aimed at by stakeholders) suffices. The use of indicators has been criticized (Wilson and Buller, 2001), most importantly for claiming objectivity while missing out on important (arguably socio-cultural) processes and their tendency to reinforce narrow-based policy objectives. However, acknowledging that indicators are a social product of negotiation (Slee, 2007) opens the way for indicators as instrument of conveying messages across actors and scales. To be useful at multiple scales, indicators should be linkable between relevant assessment levels (Pacini et al., 2003), and preferably be indicators of objectives rather than means (van der Werf and Petit, 2002). However, when indicators of the first kind are difficult, timeconsuming or costly to assess - as is often the case in Mediterranean environments - there is a need to define sustainable land management practices as means-based indicators (Zalidis et al., 2002).

The objective of this paper is to present a conceptual framework for the assessment of multiple functions and to illustrate it with a particular case study at two scales of assessment: region level and farm level, with most emphasis given to the former. The results of the case study are used to discuss the potential of the method. In the remainder of the paper, the function assessment methodology will first be described, and the case study area introduced: the Terra Quente zone within the Portuguese Agrarian Region of Trás-os-Montes. Results are thereafter presented and discussed in relation to other approaches, and conclusions with recommendations for future research are drawn.

\section{Methods}

\subsection{Conceptual framework}

\subsubsection{The 'house of functions'}

The 'house of functions' is a tool for assessing the functions of agro-ecosystems (as defined by Conway, 1987). It offers a universal 
methodology that allows stakeholders to communicate on the multiple functions of agro-ecosystems across scales. We distinguish five groups of agro-ecosystem functions (Gómez-Sal et al., 2003 refer to 'evaluative dimensions'): ecological, productive, economic, social and cultural functions. These functions can metaphorically be conceived as constituting the five lines of the silhouette of a house (symbolising the living environment). Each set of functions can even be given a specific place in this 'house of functions' (Fig. 1). Ecological functions form the foundation of the living space, comparable to the concept of ecological footprint. Productive functions depart from the foundation and provide us with products from nature: a standing wall. The second wall of the house represents the cultural functions, and is equipped with a window (the window on life). Culture links ecology to society and production links ecology to economy: the roof of the house is thus constituted by the lines representing economic and social functions, which in turn link at the ridge of the roof. If economy and society are balanced, the ridge appears just in the middle, that is to say, if they are balanced with ecology as well: if too much emphasis is put on ecology (a long base line) it leaves a gap in the roof, rendering the house uninhabitable. The opposite (too little attention paid to ecological functions) leaves a hole in the foundation.

While conceptualizing the agro-ecosystem as a house evokes the spirit of responsibility, it also symbolizes the importance of choice. The inhabitants have the option to neglect, sell out, speculate or move. It requires dedication and determination to maintain the house and the functions it fulfils.

\subsubsection{Construction of the house of functions}

For each function, indicators should be elaborated (see Section 2.2). The house of functions can be constructed by aggregating indicator scores for each type of function. These aggregated scores should be expressed as an index value (0-1) and presented in a 'house of functions' where all five function groups could obtain a maximum score of 1 (the target value). This means that each

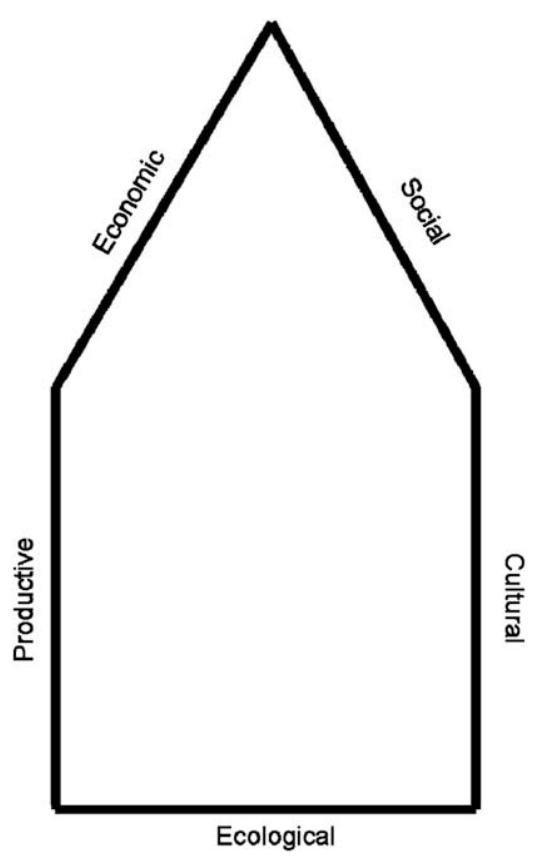

Fig. 1. The 'house of functions' and its five dimensions; (i) ecology: the fundament to the living space; (ii) production: provides us with products from nature - links ecology to economy; (iii) economy: the revenues of the system; (iv) society: the social dimension of the system; and (v) culture: the window on life - links ecology to society. Source: authors. indicator should span a range of possible values, the extremes of which need to be normalized to ' 0 ' and ' 1 ' scores. Indicators should be unambiguous and science-based. However target values will normally be elaborated in a (preferentially informed) decisionmaking process.

A second possibility for stakeholder interference is attributing weights to each indicator score before aggregation. Weighing is a facultative step in the methodology; if all indicators selected are equally important, aggregate scores could be calculated as the arithmetic mean.

There are two ways of constructing the final image of the house, depending on whether it should present a state or a goal. In case the house represents a state, it should be re-arranged in such a way that the least fulfilled function leaves a gap in the house. In case the house represents a goal (or future vision), gaps should be closed (whenever possible) by manipulating the angle between axes, normally resulting in an 'imperfect' house (Fig. 2). A construction guide is included in the Appendix.

In analogy to the notion of a normatively imperative 'strong' multifunctionality, a 'perfect' house should be strived for. However, imperfections may be well acceptable to stakeholders, or indeed society as a whole. Productive functions are about agricultural production, and their fulfilment could represent the productivist/ non-productivist tendency (with a zero-score meaning seizure to be considered an agro-ecosystem). Nevertheless, we disagree with Wilson (2007) that non-productivism is morally superior to productivism, as long as other functions are not affected; i.e. a maximisation of productive functions not altering achievement of other functions is, at least in theory, the ideal. However, the trade-offs between especially productive and ecological (but certainly also social and cultural) functions may in practice limit desired productivity.

\subsubsection{Stakeholders and SMOPS system boundaries}

Different stakeholders have different decision-making domains and horizons. However, their preference for certain values may go beyond their control. For instance, a farmer may want to sell his/her olive oil at a high price, but success may depend on effective marketing of a PDO label (product of denomination of origin). Vice versa, a regional authority may want to maintain a typical landscape, but will to large extent have to rely on the contributions farmers are willing to make. Hence, two-way traffic along hierarchical decision-making levels should be facilitated by the use of a nested approach. In the present study we distinguish between two decision-making levels: farm and regional. A farmer (decisionmaker at the farm level) addresses management decisions at parcel level and whole-farm level. For the assessment of functions, the latter was deemed to present a better assessment level, especially with regard to social and economic functions.

At both farm and regional levels, the agro-ecosystem is conceived to set the boundary to the function assessment exercise. This means that, while a certain function may have global importance (for the case of SMOPS, e.g. contribution of olive tree respiration to the maintenance of atmospheric gas exchange cycles) it has no significant value at the local agro-ecosystem level. As a consequence, SMOPS or land use changes will not affect much the provision of this service. The function 'biodiversity conservation' will similarly only be considered if it has significant local value over neighbouring agro-ecosystems. Central to the analysis is soil conservation: both because soil erosion is a major concern in SMOPS (Pastor and Castro, 1995; de Graaff and Eppink, 1999; Beaufoy, 2001; Gómez et al., 2003; Birdlife International and WWF, 2004) and because it normally has a significant impact at the local level.

It is also important to understand the relatively limited 'manoevring space' of SMOPS: unlike annual cropping systems, 


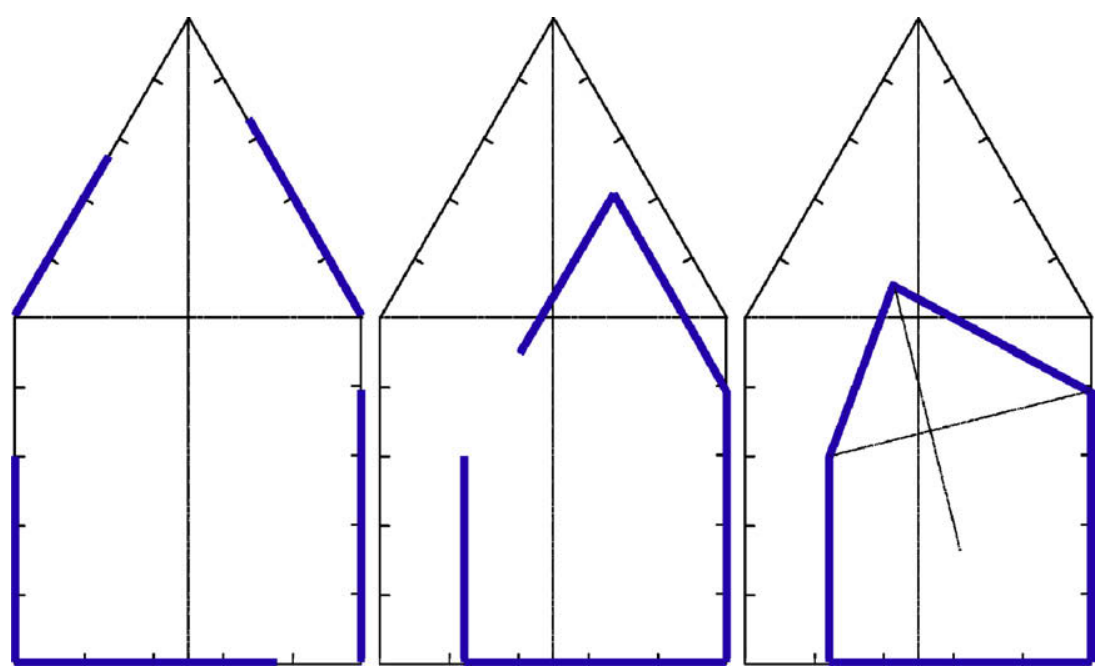

Fig. 2. Construction of the house of functions: (a) indicator values; (b) rearranging for descriptive purposes; and (c) rearranging for normative purposes. Source: authors.

structural characteristics have a pivotal significance in defining farmer options. Non-productivist action soon culminates in abandonment, so that SMOPS are likely to remain SMOPS unless strong drivers convert them to other land use (e.g. in the Vulture area, Potenza Province, Italy, SMOPS are uprooted following buy-out of small family farms for the expansion of capital-intensive wine estates). This characteristic gives SMOPS a strong area-based connotation.

\subsection{Functions of SMOPS and selected indicators}

\subsubsection{Productive functions of SMOPS}

Like any other agro-ecosystem the SMOPS by definition produce a certain amount of biomass. In order to separate agronomic from economic issues in the production process, the present analysis considers biomass production under the separate heading of 'productive functions'. Several aspects of biomass production can be considered (Table 1, where selected indicators at farm and regional levels are included):

- Productivity; the olive fruit is normally but not necessarily the main economic objective of olive farming. Apart from olives, associated and secondary products (e.g. almond, vine, cereals, firewood) can be co-produced. Olive groves can also be grazed by animals or support other types of biomass extraction.

- Product quality (notably of the olive oil produced); apart from complete chemical characterisation and organoleptic assessment, olive-oil quality is most simply expressed by its grading in acidity level.

- Stability of production; the olive tree has a natural tendency to alternate bearing. This tendency depends on variety, climatic conditions and management practices in SMOPS. A suitable indicator for stability is the Yield Consistency Index (YCI Fleskens et al., 2005).

\subsubsection{Ecological functions of SMOPS}

The ecological functions of an agro-ecosystem could be considered to comprise an extensive list of functions also attributed to the natural environment. However, management decisions or land use changes in agro-ecosystems, and specifically in SMOPS, will have no or only a marginal effect on many of the ecological functions they provide. For this illustrative case study we include the following, probably most important ecological functions of
SMOPS (Table 1), although regulation of the environmental impact of pesticides and water resources conservation may in particular cases (SMOPS 2-3) not be negligible:

- Soil conservation; the Mediterranean climate poses high erosion risk to the slopes that SMOPS are typically situated on (Fleskens and de Graaff, 2003), with potentially significant onand off-site effects. These effects can be minimized by appropriate land management.

- Wildfire control; especially in SMOPS at risk of abandonment, management interventions can play an important role in wildfire prevention.

- Biodiversity conservation; SMOPS may represent important nursery or migrating territories for flora and fauna. Especially when SMOPS provide a habitat for rare species which are absent from neighbouring (agro-)ecosystems, this could be an important function. As shown by Clergue et al. (2005), biodiversity performs a core ecological function.

\subsubsection{Economic functions of SMOPS}

The following economic functions can be distinguished:

- Income generation; the prime objective of economic activities, such as olive cultivation, is normally to provide a source of income. Additionally, agricultural subsidies accrue to SMOPS farmers.

- Food security; SMOPS contribute to self-sufficiency in products that would otherwise need to be bought at opportunity costs (subsistence production), and/or be dependent on potentially doubtful supply (for a wider perspective, see Losch, 2004).

- Export; the SMOPS can take part in production for an export market, as such contributing to national earnings (possibly in preferred hard currency).

\subsubsection{Social functions of SMOPS}

Several social functions can be attributed to SMOPS:

- Employment; the SMOPS provide employment to farmers and contract workers alike, and create jobs in back- and forwardly linked economic activities. Olive harvesting and processing especially require labour in winter, when other (agricultural) employment opportunities are most limited. 
Table 1

Functions and selected indicators for assessment of multiple functions of SMOPS at farm and regional levels

\begin{tabular}{|c|c|c|c|}
\hline Function & & Regional level indicator (unit) & Farm-level indicator $^{\mathrm{a}}$ (unit) \\
\hline Productive & $\begin{array}{l}\text { Quality } \\
\text { Stability }\end{array}$ & $\begin{array}{l}\text { Total olive production }\left(10^{3} \text { ton } \mathrm{y}^{-1}\right) \\
\text { Olive-oil content }(\%) \\
\text { Oil volume }<1^{\circ} \text { acidity (\%) } \\
\text { Yield Consistency Index (-) }\end{array}$ & Yield $\left(\mathrm{kg} \mathrm{ha}^{-1} \mathrm{y}^{-1}\right)$ \\
\hline Ecological & $\begin{array}{l}\text { Soil } \\
\text { conservation } \\
\text { Wildfire } \\
\text { control } \\
\text { Biodiversity }\end{array}$ & $\begin{array}{l}\text { Winter cover (\% area) } \\
\text { Maintenance of terraces (\% terraced area) } \\
\text { Tillage in spring (\% area) } \\
\text { Abandoned, non-pruned orchard (\% area) } \\
\text { Burnt area (ha) } \\
\text { Index value (-) }\end{array}$ & Pruning of orchard $\left(\%\right.$ area $\left.y^{-1}\right)$ \\
\hline \multirow[t]{2}{*}{ Economic } & Income & $\begin{array}{l}\text { Contribution to regional agricultural production value (\%) } \\
\text { Production cost }\left(€ \mathrm{ha}^{-1}\right) \\
\text { Olive-oil price }\left(€ \mathrm{l}^{-1}\right)\end{array}$ & Farm income from olive production $(€)$ \\
\hline & $\begin{array}{l}\text { Food } \\
\text { security } \\
\text { Export }\end{array}$ & n.a. & $\begin{array}{l}\text { Value of auto-consumption of produce }(€) \\
\text { n.a. }\end{array}$ \\
\hline \multirow[t]{3}{*}{ Social } & $\begin{array}{l}\text { Employment } \\
\text { Viability } \\
\text { Safeguard }\end{array}$ & $\begin{array}{l}\text { Seasonal labour (AWU) } \\
\text { Family labour input (AWU) } \\
\text { Migration rate (\%) } \\
\text { Dependence on on-farm income (\%) }\end{array}$ & $\begin{array}{l}\text { Hired labour input }\left(\mathrm{h} \mathrm{ha} \mathrm{h}^{-1}\right) \\
\text { Return to own labour }\left(€ \mathrm{~h}^{-1}\right)\end{array}$ \\
\hline & $\begin{array}{l}\text { Social } \\
\text { coherence }\end{array}$ & $\begin{array}{l}\text { Investment in olive orchards }(€) \\
\text { Ex-emigrants returned to engage in (hobby) farming (\%) } \\
\text { Olive farmers beyond retirement age (>65 y) }(\%)\end{array}$ & $\begin{array}{l}\text { n.a. } \\
\text { Farmer's sense of attachment to land (average score on ordinal scale) } \\
\text { Farmer's sense of contribution to communication (average score on ordinal } \\
\text { scale) }\end{array}$ \\
\hline & $\begin{array}{l}\text { Regional } \\
\text { coalitions }\end{array}$ & $\begin{array}{l}\text { Number of projects undertaken jointly by associations, } \\
\text { environmental organisations and local government }\end{array}$ & Farmer membership of farmer association (\%) \\
\hline \multirow[t]{4}{*}{ Cultural } & $\begin{array}{l}\text { Landscape } \\
\text { value } \\
\text { Recreation }\end{array}$ & $\begin{array}{l}\text { Index value (-) } \\
\text { Revenues from tourism (\% farm income) } \\
\text { Regional products sales (\% PDO label) }\end{array}$ & \\
\hline & $\begin{array}{l}\text { Cultural } \\
\text { identity }\end{array}$ & Number of products of denominated origin & Farmer's sense of self-realisation (average score on ordinal scale) \\
\hline & Cultural & Cultural events related to olive farming (\%) & Farmers undertaking harvest as a family reunion (\%) \\
\hline & heritage & $\begin{array}{l}\text { Stakeholder appreciation of the historical significance of olive } \\
\text { farming (average score on ordinal scale) }\end{array}$ & $\begin{array}{l}\text { Farmer's appreciation of SMOPS-specific cultural heritage values (pruning } \\
\text { shapes, terraces, ...) (average score on ordinal scale) }\end{array}$ \\
\hline
\end{tabular}

a If different from regional level indicator.

- Viability of rural areas (Potter and Burney, 2002; Hollander, 2004); the existence of the SMOPS may help to secure the viability of rural areas where otherwise the level of services could drop below a critical level inducing emigration.

- Safeguard function; this function assesses income security for part-time farmers. With a high share of aged farmers, olive farming complements meagre pensions. The SMOPS also provide a safety net for farmers engaging in a diversification of activities.

- Social coherence; SMOPS contribute to communication, a sense of attachment to the land and social inclusion of the elderly.

- Regional coalitions (see also Holmes, 2002); SMOPS constitute a central theme in regional rural development; through increasing levels of organisation of olive farmers in associations, which in turn interact with policy-makers and environmental organisations, they are able to form a regional coalition to enhance multifunctional rural development.

\subsubsection{Cultural functions}

Cultural functions are the hardest to assess, as they relate to more abstract concepts. Note that other classifications group these functions under information functions (de Groot, 1992). Contrary to natural ecosystems, information functions of agro-ecosystems form an intrinsic part of the culture that co-evolved with these systems. We included the following cultural functions:

- Landscape value; agro-ecosystems co-shape landscapes which receive very different appreciation from stakeholders. There is a large literature on visual qualities of landscapes (e.g. Kuiper, 2000; Stobbelaar et al., 2000; Tahvanainen et al., 2002). We developed a simple index after Pachaki (2003). This index is assembled from ten scores (range 0-1) addressing seven landscape qualities. Landscapes of SMOPS contrast greatly with adjacent landscapes under annual crops.

- Recreation; tourism makes an important economic contribution in many Mediterranean areas. However, its geographical distribution is very unequal. In rural areas, landscape, cultural heritage and development of tourism infrastructure and leisure activities are important factors in tourism promotion. For SMOPS, of direct interest are tourist expenditure in rural (farm) tourism and regional products sales.

- Cultural identity; more than other agro-ecosystems, the SMOPS with their structural characteristics reinforce a spiritual attachment of farmers to the land (Holmes, 2002).

- Cultural heritage value; SMOPS represent a long historical tradition with several specific local elements. Cultural events serve to keep traditions and knowledge of olive cultivation alive.

\subsection{Study area and data collection}

\subsubsection{The 'Terra Quente' study area}

The Portuguese Agrarian Region of Trás-os-Montes (literally: 'Beyond the Mountains') is situated in the extreme northeastern corner of the country (Fig. 3). Even today it remains characterised by a highly significant primary economic sector, absorbing $46.8 \%$ of total regional employment and producing $13.5 \%$ of regional GDP in 


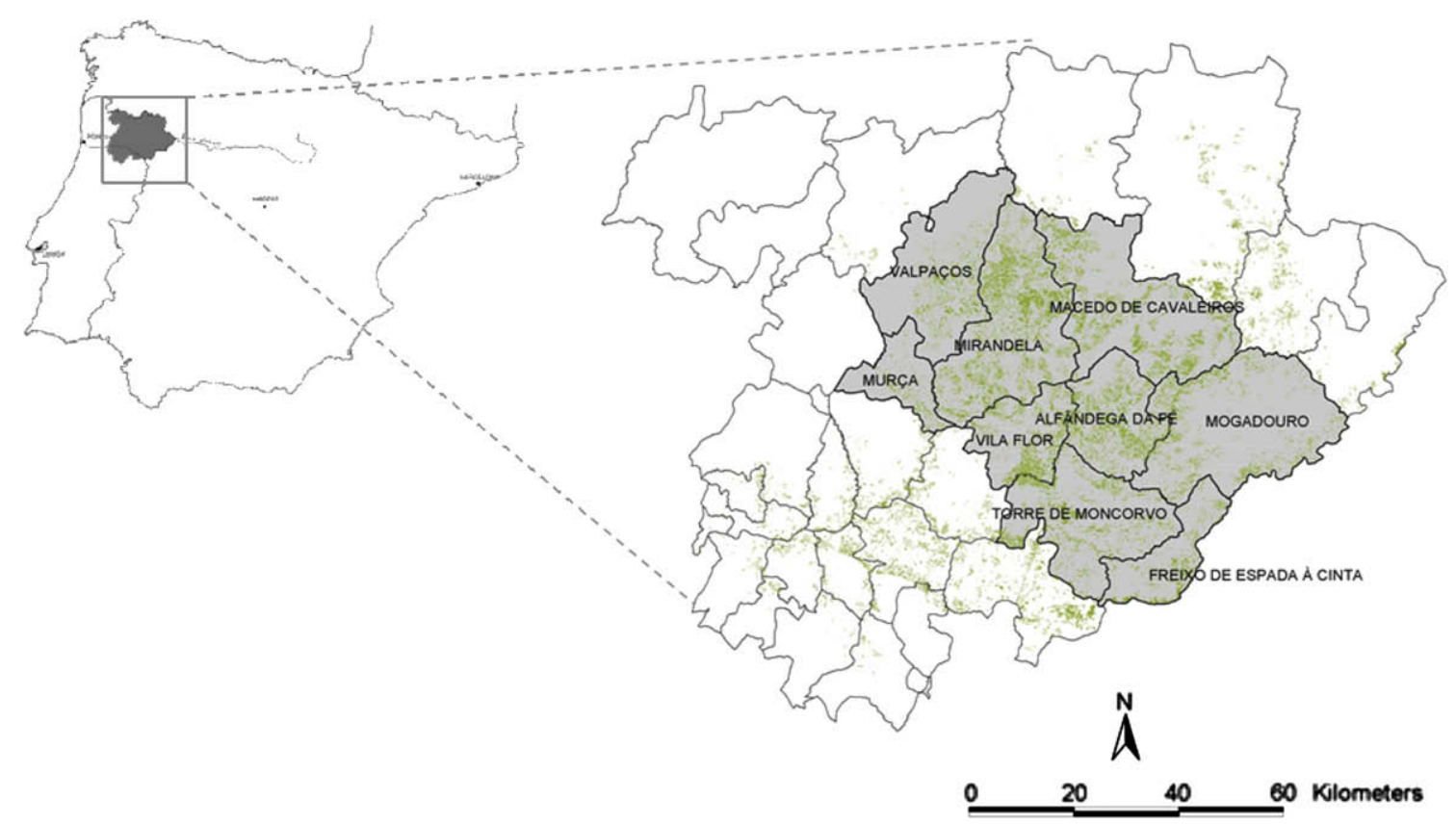

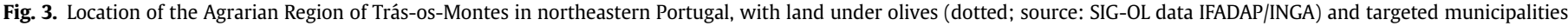
constituting the Terra Quente study area.

1995 (GPPAA, 2000). From an agro-ecological point of view, Trásos-Montes can be divided into five zones differing in climate, altitude and main agricultural systems. One of these zones is the "Terra Quente' ('Hot Land'), largely coinciding with the olive production area (Madureira et al., 1994). Nine municipalities more or less covering the Terra Quente were selected as target area for the function assessment study of SMOPS at the regional level and will subsequently be referred to as Terra Quente area. The Terra Quente area is characterised by hilly topography fluctuating between $300 \mathrm{~m}$ and $500 \mathrm{~m}$ altitude and receives an average annual precipitation of $400-600 \mathrm{~mm} \mathrm{y}^{-1}$. More than half of all farms in Trás-osMontes, and $85 \%$ of farms in the Terra Quente zone cultivate olives on an average of 1.2 ha and 2.1 ha per farm respectively (INE, 2002). The population of the Terra Quente area has decreased by more than 20\% between 1981 and 2001. Depopulation has been more severe in remote rural areas, with intra-area tendency to concentrations around towns such as Mirandela. However, most migrants have left the area for large cities outside the region.

\subsubsection{Data collection}

The functions of olive plantations in the Terra Quente area were assessed based on data collected from several sources, the most important of which was an agro-socio-economic survey of 60 olive producing farmers. This survey allowed us to distinguish different types of olive plantation systems (Table 2). This typology distinguishes five systems based on differences in tree density, slope, tree age, cultivation practices and olive production. Most orchards in the target area qualify as traditional SMOPS (SMOPS 1), although the area of semi-intensive SMOPS for olive-oil production (SMOPS 2) is considerable due to a much larger farm size. SMOPS 3-5 are less widespread. SMOPS 3 has the most intensive management and is usually irrigated, a fact associated with its focus on table olive production. It is specific of a geographical location. SMOPS 4, specific of the very steep hillslopes ('Arribas') of the Douro River and its tributaries, faces severe problems of abandonment. Organic farms are grouped in SMOPS 5 but are of relatively limited importance for the target area.

Apart from the main agro-economic survey (which excluded SMOPS 4), a specific study of 23 SMOPS-4 farmers, as well as a review of secondary data were undertaken. Expert knowledge (regional department of agriculture, technicians of farmer associations) was used to complement data. Data availability differed per function category: productive functions could be assessed quantitatively, while for some other functions expert opinion was used or informed guesses were made. A few functions were not considered due to data shortage. This resulted from the fact that the methodology for the construction of the house of functions was work in progress during field data collection, and missing data could only partly be obtained later from secondary sources. These lacunae are however not expected to have greatly affected the resultant houses of functions.

Stakeholder participation in this study was limited to the provision of information, on the basis of which the function assessment exercises were carried out. Target values were thereby constructed based on trend analysis (productive functions), comparisons with other agro-ecosystems, and/or derived from stakeholder information. These approaches may serve as examples of how stakeholders could arrive at target values themselves. Results are worked out for the regional level function assessment, and a brief comparison is made for two farm-level examples for two types of SMOPS (SMOPS 2 and 4, see below).

\section{Results}

\subsection{Assessment of SMOPS functions in Terra Quente}

\subsubsection{Productive functions of SMOPS in Terra Quente at the regional level}

When assessing the productive functions of olive orchards in Trás-os-Montes against national production figures, Trás-osMontes clearly classifies as an important olive production area with an above average standard of quality of olive oil, i.e. a low acidity level (Table 3). The olive area in Trás-os-Montes has expanded by $30 \%$ over the decade $1990-2000$, while the total agricultural area increased only marginally. Average regional olive yield (19901998) was $888 \mathrm{~kg} \mathrm{ha}^{-1}$, against $763 \mathrm{~kg} \mathrm{ha}^{-1}$ nationally (INE, 2002). Fig. 4 shows that the highest regional olive production (slightly over 100000 tons) was obtained in 1991, corresponding to an 
Table 2

Classification of SMOPS for the Terra Quente area

\begin{tabular}{|c|c|c|c|c|c|}
\hline & SMOPS 1 & SMOPS 2 & SMOPS 3 & SMOPS 4 & SMOPS 5 \\
\hline & Traditional & Semi-intensive (olive oil) & Semi-intensive (table olive) & Arribas, in process of abandonment & Organic \\
\hline Number of farms & 22800 & 1300 & 2250 & n.a. $\left(\sim 4000^{c}\right)$ & 220 \\
\hline Olive area $\left(10^{3}\right.$ ha $)$ & 30 & 15 & 4.8 & n.a. $\left(\sim 7.0^{c}\right)$ & 3.2 \\
\hline Tree density (trees ha ${ }^{-1}$ ) & \pm 100 & \pm 200 & \pm 280 & Irregular & \pm 100 \\
\hline Slope & Any & Low - moderate & Strong - steep & Strong - steep & Any \\
\hline Age $(y)$ & Mainly $>50$ & $<20$ & Variable & $>50$ & Mainly $>50$ \\
\hline Soil tillage $\left(\right.$ no $\left.^{-1}\right)$ & $1-3$ & $1-3$ & $1-3$ & $0-2$ & $1-3$ \\
\hline Weed control method & Tillage & Tillage & Tillage & Tillage, grazing & Tillage \\
\hline Irrigation & No & No & Yes (drip) & No & No \\
\hline Fertilisation method & Chemical & Chemical & Chemical & Chemical/organic, none & Organic \\
\hline Fitosanitary treatments $\left(\mathrm{y}^{-1}\right)$ & $0\left(2^{\mathrm{a}}\right)$ & $0\left(2^{\mathrm{a}}\right)$ & 4 & 0 & $0-2$ \\
\hline Pruning frequency $\left(\mathrm{y}^{-1}\right)$ & 0.50 & 0.50 & 1.0 & $0-0.5$ & 0.33 \\
\hline Harvesting method & Semi-mechanised & Semi-mechanised & Manual & Manual/semi-mechanised, none & (Semi-)mech \\
\hline Production $\left(\mathrm{kg} \mathrm{ha}^{-1}\right)$ & $1000-1200$ & $2000-2500$ & $3500-5000$ & $<1000$ & $800-1000$ \\
\hline Consistency of prod $\left(\mathrm{YCI}^{\mathrm{b}}\right)$ & Low $(0.53)$ & Low $(>0.53)$ & High (0.76) & Low $(<0.53)$ & Low $(>0.53)$ \\
\hline Farm size & Small & Medium - large & Variable & Variable & Medium - large \\
\hline
\end{tabular}

Sources: Duarte et al. (2004) and Eicher (2005).

${ }^{\text {a }}$ If under integrated protection.

b $\mathrm{YCI}=$ Yield Consistency Index; $0 \leq \mathrm{YCl} \leq 1$, with high values indicating stable production - for more details see Fleskens et al. (2005)

${ }^{c}$ Figures are estimated as abandoned areas are not registered in agricultural statistics.

average yield of $1625 \mathrm{~kg} \mathrm{ha}^{-1}$. We selected these values as targets (Table 4). Yield consistency is not very high (an average YCI of 0.55 over 1990-2001), although the YCI reached a maximum of 0.89 . The percentage of olive oil of high quality, expressed as oil with acidity $<1^{\circ}$, was $78 \%$ in 1999 and 2001 (Fig. 4). The highest oil content was obtained in 1990: slightly above 19\% (Fig. 4).

Table 4 shows the scores on abovementioned indicators for the period 2002-2004. Percentual achievement was assessed on the reference scale constructed from highest and lowest values of Fig. 4. Considering weights emphasing quantity of production, the aggregate score for the productive function was assessed at $76 \%$.

\subsubsection{Ecological functions of SMOPS in Terra Quente at the regional level}

Ninety-five percent of the olive area is on hilly and mountainous land more than half steeper than 15\% (DEASR, 2004b), and 33\% is affected by erosion (de Figueiredo et al., 2002). Two soil conservation indicators were selected: (1) the percentage of area protected by a winter cover and (2) the percentage of terraced area where terraces are well-maintained. Both target levels are set at $100 \%$. Eighty percent of farmers practice between one and three tillage operations per year. In most cases, this includes a tillage operation in autumn, and low soil cover in winter as a consequence. No regional data were available about terrace maintenance.

Olive orchards are considered very effective as firebreaks. Out of all southern European countries, Portugal suffered most wildfires between 1980 and 2003 (398682 occasions, 38\% of total) (Agronoticias, 2005). Moreover, wildfire problems in Trás-os-Montes strongly increased over this period. Fig. 5 shows that the number of wildfire outbreaks per area unit is negatively correlated with the

Table 3

Importance of regional and national olive production in 2001

\begin{tabular}{lrcl}
\hline & National & Trás-os-Montes & \% of national \\
\hline Processed olives (ton) & 218523 & 74043 & 33.9 \\
Olive oil (hl) & 349502 & 128676 & 36.8 \\
With acidity $<1^{\circ}$ & 148328 & 100705 & 67.9 \\
With acidity $1-2^{\circ}$ & 108128 & 22223 & 20.6 \\
With acidity $>2^{\circ}$ & 93050 & 5748 & 6.2 \\
Oil yield $(1 / 100 \mathrm{~kg}$ ) & 16 & 17 & 38.9 \\
Table olives (ton) $^{\mathrm{a}}$ & 7550 & 2937 & \\
\hline
\end{tabular}

Source: INE agricultural statistics in DEASR (2004a)

a For the year 2000. share of regional land under olives (Pearson correlation coefficient of $-0.394, P<0.05$ ), but not with the percentage of total agricultural land in use. These data implicitly show the firebreak effect of olive orchards, especially if one considers that olive cultivation in Trás-os-Montes is confined to the Terra Quente area. This zone has a pronounced hot and dry summer where one would expect higher fire risk (93\% of annual burnt area in Portugal results from Summer wildfires - Pereira et al., 2005). If we estimate the burnt area of olive groves to be $25 \%$ of the proportional share of olive orchards of
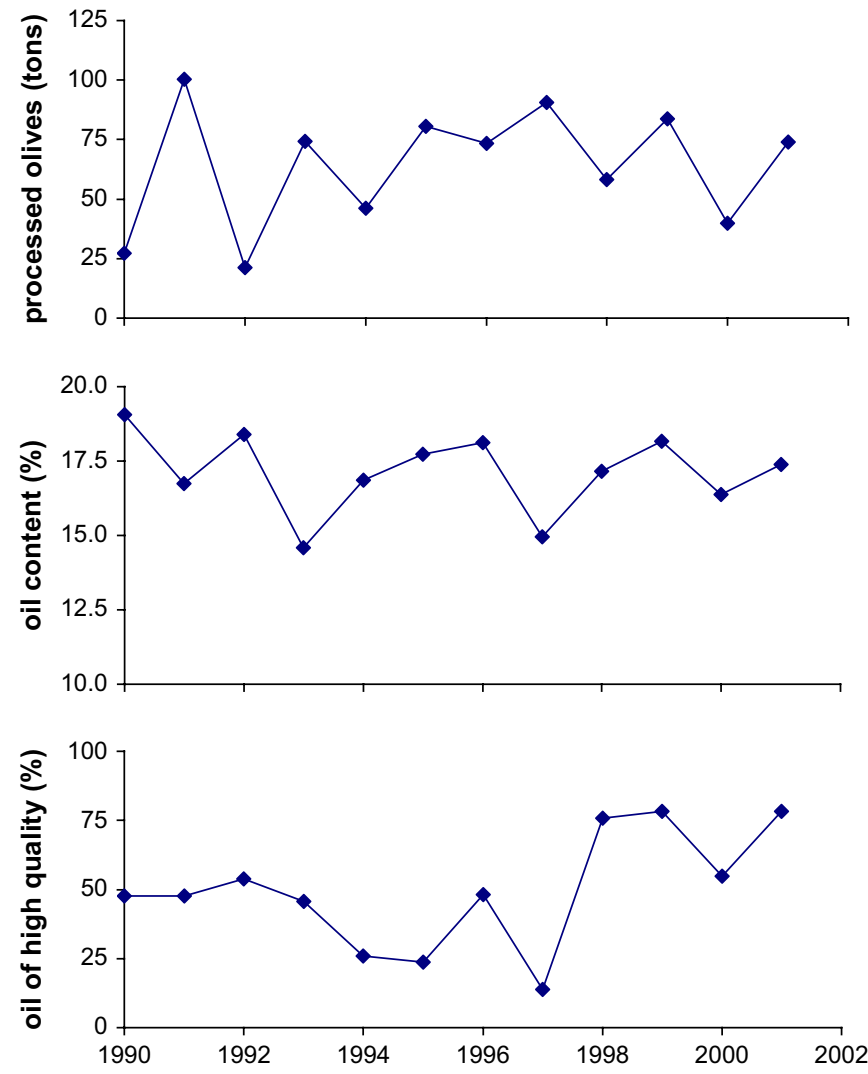

Fig. 4. Trends of indicators of productive functions of olive growing in Trás-os-Montes, 1990-2001 (data from INE). 
Table 4

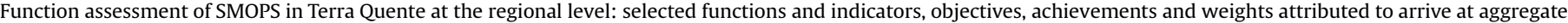
scores

\begin{tabular}{|c|c|c|c|c|c|c|c|c|}
\hline Function & & Indicator (unit) & Objective & $\begin{array}{l}\text { Reference } \\
\text { scale }\end{array}$ & $\begin{array}{l}\text { Achievement } \\
(2002-2004)\end{array}$ & $\begin{array}{l}\text { Id. } \\
(\%)^{\mathrm{c}}\end{array}$ & $\begin{array}{l}\text { Weight } \\
(\%)\end{array}$ & $\begin{array}{l}\text { Aggregate } \\
\text { score }(\%)\end{array}$ \\
\hline \multirow[t]{4}{*}{ Productive } & Productivity & Total olive production $\left(10^{3}\right.$ ton $\left.\mathrm{y}^{-1}\right)$ & 100 & $20-100$ & $72.7 \pm 7.1$ & 66 & 50 & 76 \\
\hline & & Olive-oil content (\%) & 19 & $14-19$ & $17.5 \pm 0.6$ & 70 & 10 & \\
\hline & Quality & Oil volume $<1^{\circ}$ acidity (\%) & 78 & $14-78$ & $70.4 \pm 9.4$ & 88 & 20 & \\
\hline & Stability & Yield Consistency Index (-) & 0.9 & $0.1-0.9$ & $0.81 \pm 0.18$ & 89 & 20 & \\
\hline \multirow[t]{5}{*}{ Ecological } & Soil & Winter cover (\% area) & 100 & $0-100$ & 20 & 20 & 40 & 45 \\
\hline & conservation & Maintenance of terraces (\% terraced area) & 100 & $0-100$ & n.a. & & & \\
\hline & Wildfire & Tillage in spring (\% area) & 100 & $0-100$ & 50 & 50 & 20 & \\
\hline & control & Abandoned, non-pruned orchard (\% area) & 0 & $100-0$ & 13 & 87 & 20 & \\
\hline & & Burnt area (ha) & $\begin{array}{l}60 \\
(0.075 \%)\end{array}$ & a & $91 \pm 18$ & 48 & 20 & \\
\hline \multirow[t]{3}{*}{ Economic } & Income & Contribution to regional agricultural production value (\%) & 8.5 & $0-8.5$ & $6.7^{\mathrm{b}}$ & 79 & 33 & 85 \\
\hline & & Production cost $\left(€ \mathrm{ha}^{-1}\right)$ & 867 & & 955 & 90 & 33 & \\
\hline & & Olive-oil price $\left(€ \mathrm{l}^{-1}\right)$ & 2.62 & $0-2.62$ & 2.26 & 86 & 33 & \\
\hline \multirow[t]{7}{*}{ Social } & Employment & Total labour input (AWU) & 5000 & & 3372 & 67 & 50 & 70 \\
\hline & & Seasonal labour input (AWU) & n.a. & & n.a. & & & \\
\hline & Viability & Migration rate (\% between 1991 and 2001) & -5.7 & a & -8.2 & 56 & 20 & \\
\hline & Safeguard & Investment in olive orchards $(\%<5 \mathrm{y})$ & 10 & $0-10$ & 7.5 & 75 & 20 & \\
\hline & Social & Ex-emigrants returned to engage in (hobby) farming (\%) & n.a & & n.a. & & & \\
\hline & coherence & Olive farmers beyond retirement age ( $>65 \mathrm{y})(\%)$ & 24 & $0-24$ & 39 & 100 & 10 & \\
\hline & $\begin{array}{l}\text { Regional } \\
\text { coalitions }\end{array}$ & $\begin{array}{l}\text { Number of projects undertaken jointly by associations, environmental } \\
\text { organisations and local government }\end{array}$ & n.a. & n.a. & 2 & & & \\
\hline \multirow[t]{6}{*}{ Cultural } & $\begin{array}{l}\text { Landscape } \\
\text { value }\end{array}$ & Index value $(0-10)$ & 6.4 & $0-6.4$ & 4.9 & 77 & 70 & 70 \\
\hline & Tourism & Revenues from tourism (\% farm income) & n.a. & & n.a. & & & \\
\hline & & Regional products sales (\% PDO label) & 5.0 & $0-5$ & 2.7 & 54 & 30 & \\
\hline & $\begin{array}{l}\text { Cultural } \\
\text { identity }\end{array}$ & Number of olive products of designated origin & n.a. & n.a. & 2 & & & \\
\hline & Cultural & Cultural events related to olive farming (\%) & n.a. & & n.a. & & & \\
\hline & heritage & $\begin{array}{l}\text { Stakeholder appreciation of the historical significance of olive farming } \\
\text { (average score on ordinal scale) }\end{array}$ & n.a. & & n.a. & & & \\
\hline
\end{tabular}

Sources: data from agro-socio-economic survey, statistical data from INE, IDRHa \& DGRF, and expert consultation (see also main text).

${ }^{a}$ In absence of a reference scale, a penalty on excess is calculated according to $1-((y-x) / x)$.

b Value in 2000.

c Achievement percentages are calculated over the range given by the reference scale, or by multiplying the penalty on excess by 100 .

total agricultural land, to account for relatively low fire risk in olive orchards and avoid double counting of repeated fire outbreaks in the same area, the average orchard area burnt would be 60 ha y $^{-1}$. For the years 2002-2004, this indicator value was $91 \pm 18$ ha $\mathrm{y}^{-1}$. Tillage in spring is a crucial factor in reducing fire risk. We estimate that about $50 \%$ of the olive orchard area receives this treatment. Another important management intervention to avoid fires is pruning. According to DEASR (2004a), in 13\% of the regional olive area olive trees are inadequately cared for, which usually starts with the neglect of pruning (Eicher, 2005).

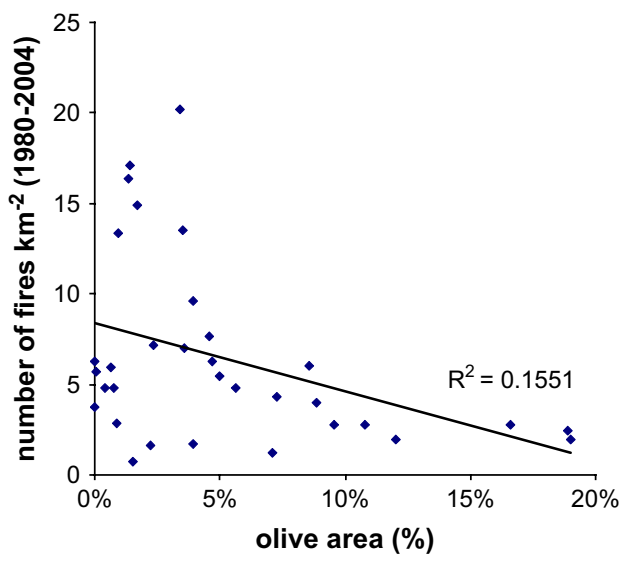

The olive plantations are part of diversified agricultural landscapes, next to olives composed of other permanent crops, annual crops and forest. As a consequence they may have a beneficial effect on biodiversity, especially SMOPS 4 and 5. Inappropriate hunting practices have in some instances considerably reduced the population of some birds like thrushes (Turtidae) and starlings (Sturnidae). Intensified olive plantations negatively affect pseudosteppe birds of high conservation value (Santos and Cabral, 2004) However, insufficient data were available to include biodiversity conservation in the function assessment study.

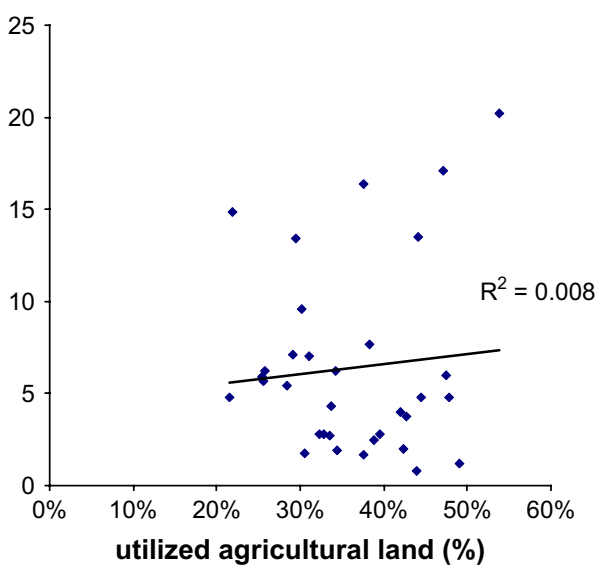

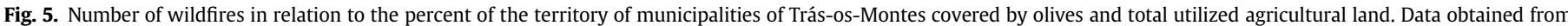
DGRF (2005). 
3.1.3. Economic functions of SMOPS in Terra Quente at the regional level

Between 1995 and 1999 olive production in Trás-os-Montes contributed on average $8.5 \%$ of regional agricultural production value (INE, 2002). The latest year for which data are available, 2000, the contribution was $6.7 \%$. The importance of back- and forward linkages, especially processing industries, as a source of added value to the regional product could not be quantified.

Production costs of olive-oil amount to $€ 955 \mathrm{ha}^{-1}$, or $€ 3.82 \mathrm{l}^{-1}$, taking into account labour, equipment, intermediate consumption, processing and other costs. Labour (opportunity) costs of farm family members are thereby valued at market wage rate, which could be an overestimation. The average price of olive-oil sold (2004) was $€ 2.26 \mathrm{I}^{-1}$; to cover production costs $€ 2.62 \mathrm{l}^{-1}$ (plus the current level of subsidies of $€ 1.20 \mathrm{l}^{-1}$ ) would be necessary or alternatively, production costs should be reduced to $€ 867 \mathrm{ha}^{-1}$ (Fleskens, 2005).

Nation-wide, olive oil comprised $€ 13.9$ million (4.3\%) of Portuguese agricultural exports, against $€ 73.8$ million (4.2\%) of agricultural imports (averages over 1997-1999) (GPPAA, 2000). No comprehensive regional data could be found, but assuming that twice the national per capita consumption of olive oil $\left(5.7 \mathrm{~kg} \mathrm{y}^{-1}\right.$, IDRHa, 2005) is consumed locally, more than $80 \%$ of olive-oil production is sold outside of the target area. Figures do exist for about $3 \%$ of the olives produced in the target area that are marketed as Product of Denominated Origin (PDO), of which more than $75 \%$ is sold outside the production area (IDRHa, 2005).

Out of the remaining $20 \%$ of olive oil produced, three-fifths (12\%) is sold locally; about $8 \%$ of the regional olive production is used for auto-consumption, and this figure is definitely higher for traditional plantations. For the benefiting families, the value of this share is higher than its economic one, because it contributes to food security at a lower cost than if they would need to buy olive oil from retail shops.

\subsubsection{Social functions of SMOPS in Terra Quente at the regional level}

The importance of olive production as a growing agricultural activity has also increased its contribution to regional agricultural employment. Multiplying labour input data per area unit for the different SMOPS types from the farmer survey by the respective areas occupied by each SMOPS gives a total of 3372 Annual Working Units (AWU) in the target area (conservative estimate), $12 \%$ of the regional agricultural employment of 29221 AWU (INE, 2001). Employment generation of the SMOPS is thus in relative terms a more important function than income generation.

The safeguard function, contributing to the security of household incomes by complementing other income sources is also very important, as more than $66 \%$ of small producers (those having an olive area under 5 ha) and 44\% of medium-sized producers (those having between 5 ha and 25 ha of olive orchards) depend primarily on off-farm income (GPPAA, 2002). For the traditional olive plantation systems these figures are higher, while semi-intensive and organic systems depend to a much higher extent on on-farm income. In isolation, the importance of on-farm income is not very informative to assess the safeguard function. However, if we assume that olive orchards have an economic life of $50 \mathrm{y}, 10 \%$ of the olive area should be replanted in $5 \mathrm{y}$ (target value). The investment involved, when made by people not primarily dependent on olive growing, is another indicator of the safeguard function. The actual percentage of orchards younger than $5 \mathrm{y}$ is $7.5 \%$.

The contribution of olive growing to the viability of the area is important considering that the region has a negative migration rate and that the density of industrial and services firms is one of the lowest in the country $\left(0.3 \mathrm{~km}^{-2}\right.$, against $2.8-4.7 \mathrm{~km}^{-2}$ in other northern Portuguese regions; GPPAA, 2002). A simple calculation shows that the 158 recognized olive-oil mills existing in Trás-os-Montes (12 $273 \mathrm{~km}^{2}$ ) in 2001 directly contributed with more than $4 \%$ to this service level index, in which context it should be realized that the bulk of firms is concentrated in the towns and oil mills are among the few extant firms in rural areas. The olive sector as a whole, through its importance to regional employment, helps to maintain the level of other (noncommercial) services necessary to ensure agreeable living.

Olive farming contributes to social coherence: because of the structural characteristics of SMOPS, with trees passing from generation to generation, many people quitting farming do not give up or sell their groves. It is quite common for ex-emigrants to return to their village of birth after retirement to reinvigorate the tradition of olive farming. While $24 \%$ of the population over $15 \mathrm{y}$ of age of Terra Quente has passed the age of $65,39 \%$ of SMOPS farmers is 65 or older (GPPAA, 2002). Thus, SMOPS accommodate the inclusion of a substantial number of retired individuals who can participate in rural life and communication and form a part of the rural community.

There are some indications that SMOPS farmers, regional government and environmental organisations are forming coalitions to further rural development. SMOPS farmers' membership of producer associations was initially driven by policy which required olive mills to be legally recognized and acting on behalf of olive producers to administer subsidies. However, associations have been active in developing markets for olive oil and tourism. These activities of strategic interest to promoting a multifunctional region have strengthened ties between regional stakeholders. Two notable projects were identified: (i) the laying out of a touristic Trás-os-Montes Olive-Oil Itinerary signposting olive producers, oil mills, shops selling olive oil, hotels and restaurants and (ii) the creation of the National Park Douro International, in 1998, to protect the natural and cultural heritage in a remote part of the region. Small-scale olive farming on steep slopes contributes to both natural and cultural heritage values, and the park administration, local government and olive producers are seeking ways to maintain olive groves in the area suffering intense depopulation.

\subsubsection{Cultural functions of SMOPS in Terra Quente at the regional level}

The aggregate landscape value of SMOPS was derived from individual SMOPS scores (Table 5). The target value was assessed in a similar fashion by adjusting partial index scores to the desired level. As such, an average landscape value of 4.9 was obtained while the target value was set at 6.4.

Direct revenues from tourism attributable to olive growing could not be assessed. The importance of regional cultural identity was assessed using the percentage of olive oil sold with PDO label as an indicator. Currently this is $2.7 \%$, while the crop's expertestimated potential market share is $5 \%$.

SMOPS have contributed to distinct cultural identities of their farmers. Cultural practices in olive groves such as pruning and soil management evolve from long, often geographically localized traditions. Owing to its greater visibility than similar traditions in annual crops, the cultural identity of SMOPS farmers is strong. Two PDO labels specific to olive production have been defined for the Terra Quente area: Trás-os-Montes olive oil and Negrinha de Freixo table olives, the latter being characteristic of SMOPS 3, the only specialized table olive production system in Portugal. The mountain ranges surrounding Terra Quente SMOPS farmers, where herding and annual crops dominate, have reinforced a geographical sense of identity, typified by the expression "Três mêses de inverno, nove mêses de inferno" (three months of winter, nine months of hell).

Olive farming in Terra Quente has produced cultural heritage values. Many regional cultural events (not quantified) are directly 
Table 5

Landscape values for SMOPS in the Terra Quente area and for SMOPS types 2 and 4

\begin{tabular}{|c|c|c|c|c|c|}
\hline \multirow[t]{2}{*}{ Landscape quality ${ }^{\mathrm{a}}$} & \multirow[t]{2}{*}{ Indicator } & \multicolumn{4}{|c|}{ Scores (partial scores ranging $0-1$ ) } \\
\hline & & Regional target & Regional average & SMOPS 2 & SMOPS 4 \\
\hline \multirow[t]{2}{*}{ 1. Merged into natural landscape } & Presence of natural and semi-natural patches & 0.5 & 0.2 & 0.1 & 0.8 \\
\hline & Presence of old, big trees & 0.4 & 0.4 & 0.2 & 0.7 \\
\hline \multirow{2}{*}{ 2. Spatial and temporal variety } & Frequency of tillage operations & 0.8 & 0.3 & 0.3 & 0.8 \\
\hline & Average plot size & 0.6 & 0.8 & 0.6 & 1 \\
\hline 3. Richness & Presence of stone walls/terraces & 0.2 & 0.2 & 0.1 & 0.9 \\
\hline 4. Smoothness or non-disruption & Presence of non-managed abandoned area & 1 & 1 & 1 & 0.3 \\
\hline 5. Special effects & Special effect bonus (almond, flowers, dramatic landscape features) & 0.4 & 0.4 & 0.2 & 1 \\
\hline 6. Accessibility & Accessibility & 0.5 & 0.4 & 0.6 & 0.2 \\
\hline \multirow[t]{2}{*}{ 7. Environmental soundness } & Presence of signs of erosion & 1 & 0.4 & 0.3 & 0.7 \\
\hline & Presence of areas affected by fire & 1 & 0.7 & 0.8 & 0.3 \\
\hline Aggregate landscape value & Index value (sum of all partial scores) & 6.4 & 4.9 & 4.2 & 6.7 \\
\hline
\end{tabular}

a After Pachaki (2003).

or indirectly related to olive cultivation. Heritage values stem from the historical significance of olive farming. The Terra Quente has supposedly been the point of entry of olive cultivation in Portugal in the sixteenth century (Eicher, 2005). The tradition of small-scale family farming has led to a very different heritage from more extensive large-scale olive farming in other Portuguese regions, most notably Alentejo.

\subsection{Applying the house of functions concept to Terra Quente SMOPS at regional and farm levels}

The regional indicator scores reproduced in Table 4 can be presented as a house of functions (Fig. 6). Ecological functions appear to be in shortest supply with the set of indicators used. Although a closed house can be constructed, it is highly unstable because the ecological base is too small; improving environmental performance is thus the first priority. After these improvements are made, an inhabitable (closed) house can be constructed, but as social functions are also relatively weak, another imperfect house would result. If this silhouette would be used for normative purposes, the question is whether stakeholders accept the house as it is, or whether they would like to make further improvements, whereby enhancing social functions would have to receive priority.

When regional indicators are replaced by farm-level indicators (Table 1, scores not shown), individual SMOPS can be compared (Fig. 7). Taking as an example SMOPS types 2 (semi-intensive) and 4 (in process of abandonment), aggregate scores for productive and economic functions vary widely, while scores for cultural functions differ less. Also scores for ecological functions do not deviate much. This is a result of aggregating indicator scores for soil conservation and wildfire control which show opposite tendencies along an intensity of production gradient.

For SMOPS 4, closing the house silhouette in its present state is possible, although this would result in a house with a flat roof. If this silhouette were used for normative purposes, the question would be whether the farmer accepts that this type of orchards performs poorly on economic and social functions (de facto making him/her a hobby farmer), or whether he/she would attempt to enhance these functions. In the first case, economic and social functions would perhaps be transferred to other activities not included within the SMOPS (e.g. receiving a pension to complement farm income).

The overall house of SMOPS 2 type of orchards resembles the situation of regional SMOPS (Fig. 6), performing better on most functions except ecological (no difference) and cultural ones. A closed house can be constructed but remains highly unstable unless ecological functions are enhanced. Once ecological performance is improved, cultural functions become a priority for enhancement.
Comparing Figs. 6 and 7, we can see that farmer and regional level priorities may be very different. While overall regional priority is improving environmental performance of SMOPS, farmers with SMOPS 4 are primarily concerned with economic and social functions. SMOPS 2 farmers could agree on the importance of enhancing ecological functions, but are less concerned with the second regional priority, social functions. Traditional orchards (SMOPS 1) take an intermediate position between SMOPS 2 and 4, and score lowest on economic and ecological functions. This may illustrate that a strategy for effective planning should start with communication between stakeholders. Ideas on how the house of functions can contribute to this are elaborated upon in the discussion.

\section{Discussion}

While Trás-os-Montes is Portugal's most important olive production area, it must be remarked that in an international context, local olive production systems are predominantly lowproductive and traditionally managed (Beaufoy, 2001; Fleskens and de Graaff, 2003). Portuguese agriculture has suffered more important abandonment processes than other southern European countries (Margaris et al., 1996). In this respect, the drive to value multiple functions maybe more important here than elsewhere, but nevertheless the process is symptomatic of a much more widespread trend. A further impetus is to be expected from the recent (2006) introduction of single-farm payment schemes in the CAP regime for olive cultivation. As payments are based on past production in the reference period 1999-2002, plantations which have not or only recently been modernised, will not receive additional future subsidy benefits from investment in productive capacity. Investing in diversification could be a viable alternative, with olive farming performing a safeguard function.

Makhzoumi (1997) emphasizes that olive (and carob) plantations of Cyprus with multiple productive functions are in decline due to economic reasons, while these agro-ecosystems fulfil important social and cultural functions. At a higher level of abstraction, Tait (2001) suggests to differentiate a priori between intensive and extensive forms of production requiring different approaches to address multifunctionality. Siebert (2004) reports on the importance of Cretan traditional agriculture (including traditional olive orchards) to conserve biodiversity, and suggests that supporting these systems for this aim may be much more beneficial than subsidizing 'modern' agriculture for enhancing biodiversity and landscape value.

The assessment of functions of SMOPS was undertaken here at two scales: the regional and farm levels. More scales could be added, whereby intermediate stakeholders (such as local 


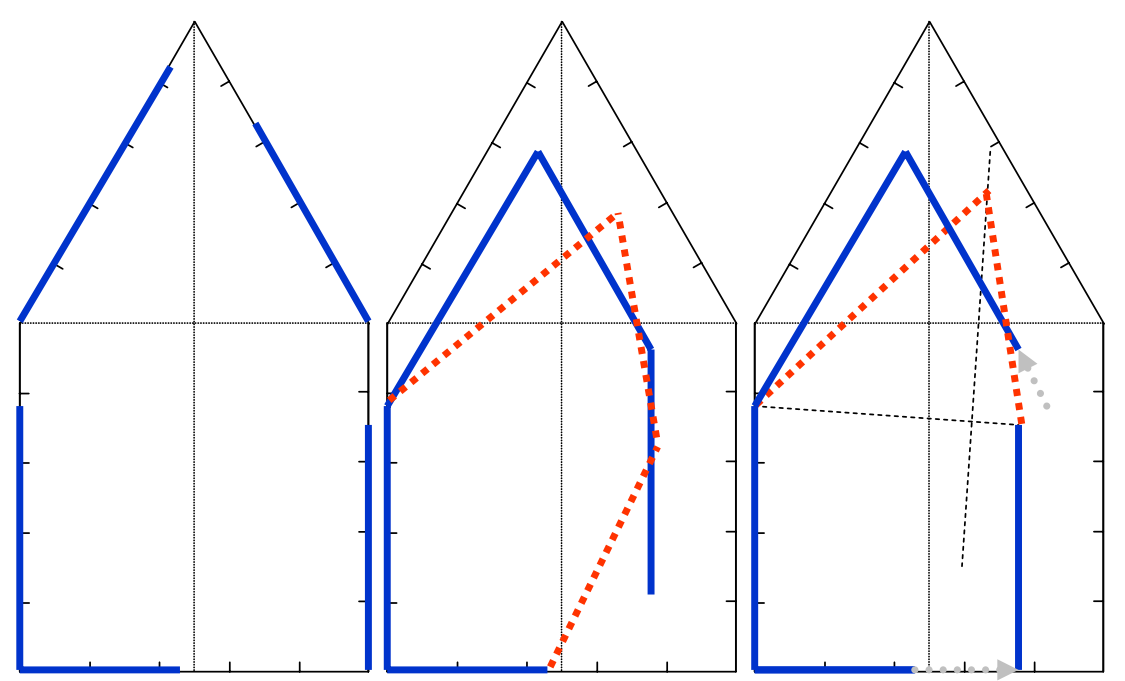

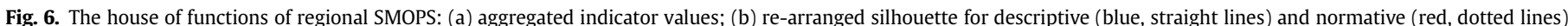

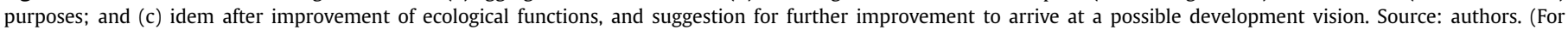
interpretation of the references to colour in this figure legend, the reader is referred to the web version of this article.)

governments) should then participate in two adjacent assessment levels and act as communicator between them. Lopez Ridaura (2005) presents such a multi-scale methodology based on attributes of sustainability. Each stakeholder could be characterised by pursuing different goals captured by different system productivity, stability, reliability, resilience and adaptability indicators. In a formal resource allocation model, goals at the lowest decisionmaking levels act as constraints at higher aggregation levels. While the approaches are not mutually exclusive, it seems that the function assessment methodology presented here may provide more opportunities for situations in which constraints are imposed upon lower aggregation levels (e.g. cross-compliance regulations). Moreover, multifunctionality may find its most direct expression at lower aggregation levels, being both increasingly complex to grasp at higher hierarchical levels as well as in need of a way of assessing the socio-political relationships between those levels, which may either advance or obstruct the potential of local farming systems to develop towards multifunctionality (Wilson, 2007).
In order to advance multifunctionality, socio-political relationships are needed that encourage participation. A report by BBO (1999) discusses experiences with the creation of stakeholder platforms. In many cases, resource conflicts led to their creation, and conflict resolution was their main goal. However, developing partnerships in areas where there is no explicit conflict also poses a challenge, as successfully developing potential functions requires synergy. Recently, quite some attention is paid in the literature on how to achieve multifunctionality, both at the farmer level, with focus on entrepreneurial skills and networks (Clark, 2005; Wortmann et al., 2005), and at the policy level, where strategies should enhance desired functions without negatively affecting farmers' livelihoods, i.e. economic and social functions - most importantly income generation, employment and viability of rural areas (Hodge, 2000; Pretty et al., 2001). Farm structural characteristics, which in our paper are to a large extent SMOPS-specific, form a third factor influencing the options for decision-making to achieve multifunctionality.

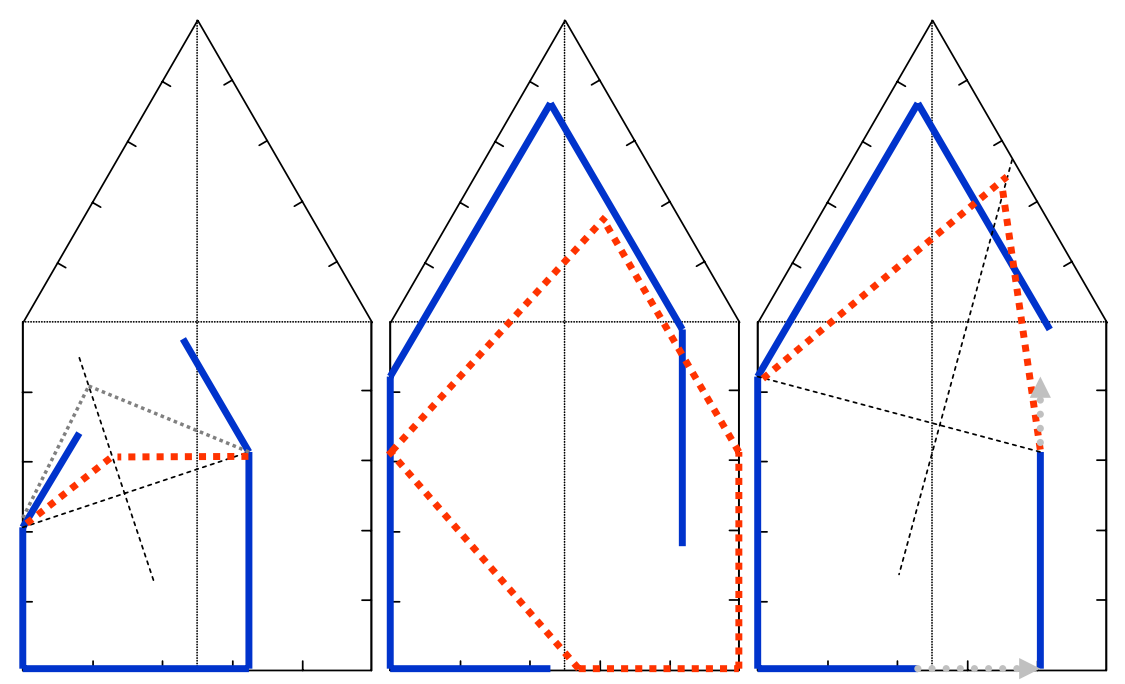

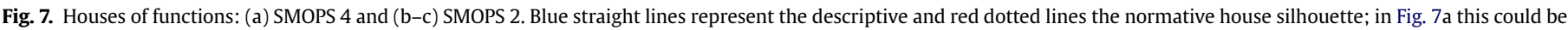

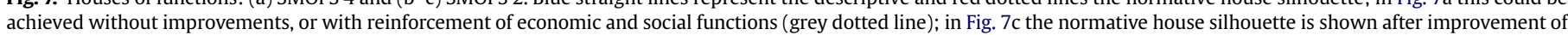

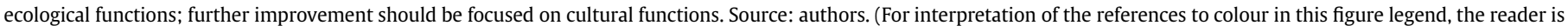
referred to the web version of this article.) 

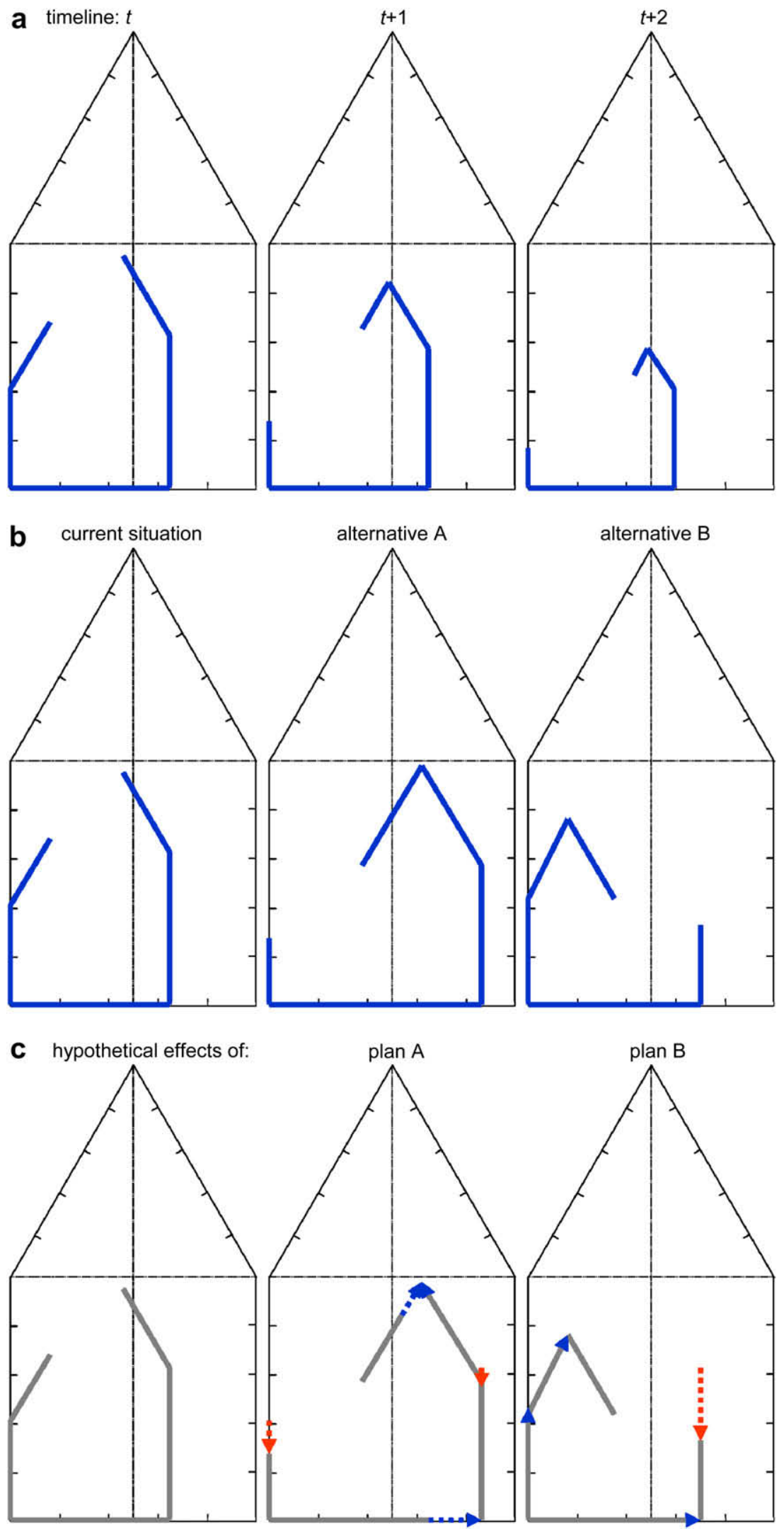

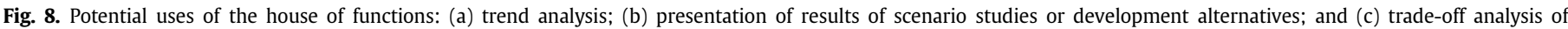
development alternatives: hypothetical effects of improving environmental performance (plan A) or maintaining the productive function (plan B). Source: authors. 
Although not fully explored in this paper, finding adequate indicators for social and cultural functions may be difficult. Where we could not determine suitable direct indicators, we experimented with stakeholders' appreciation of functions expressed on an ordinal scale (e.g. 1-5). Taking the average appreciation of a representative sample among the stakeholder group, a reliable indication could be found. This approach worked well (Eicher, 2005), but admittedly could be substantially improved by a more profound analysis of factors influencing farmers' self-identity (Burton, 2004).

Function assessment and its visualization as the house of functions should be further tested in stakeholder platforms to judge its usefulness in consensus-building and conflict resolution. Departing from a house representing the current state, stakeholders may note a trend in the direction of crumbling down or building up. They may also indicate their desired developments. The methodology thus resembles a SWOT (Strengths-WeaknessesOpportunities-Threats) analysis, with the difference that it also immediately visualizes viability. As such it provides a potentially powerful tool for the following situations (Fig. 8):

- Monitoring trends in the fulfilment of functions over time, either as a result of autonomous development or introduction of (environmental) policies.

- Presentation of the results of scenario studies aided by various 'houses', and/or discussing the relative attention that needs to be paid to each function category (axis) in development plans.

- Evaluation of how intervention in one function affects system performance in other functions (trade-offs).

A flaw in the reported application of the methodology is the aggregation of various functions. For instance, a high soil conservation score and low wildfire control score were averaged out in the process of assigning scores for ecological functions. This could be partially resolved by showing the indexed range of individual function scores or the standard deviation of the aggregated function group value. Individual functions could be weighted or a single most important function could be selected to evaluate alternatives. Individual functions could also be weighted by expressing values in uniform units, i.e. monetary valuation (for a state-of-the-art, see Madureira et al., 2007; Randall, 2007).

Notwithstanding these difficulties, the house of functions is probably a more informative tool for decision-making than single aggregate indices, each of which would only serve a narrow field of applicability (Jollands, 2006). Moreover, the concept visualizes trade-offs between functions, and thus allows a discussion of the jointness of production of commodities and non-commodities (Abler, 2001). Another frequently used tool to present indicator scores is the spider diagram. While the strength of the spider diagram lies in its capability to simultaneously present multiple scores with only an implicit limit on the number of indicators, it is not explicit about the importance of various functions. The 'house of functions' can rapidly show the most significant weaknesses of a system: it is immediately obvious that a house with, say, no foundation cannot be longlived. The house of functions may thus be used as a rapid assessment tool.

Contrasting stakeholder views in multifunctional agriculture were also presented by Kaljonen and Rikkonen (2004). While they observed important levels of agreement between stakeholders, they argue that due to the challenging future of agriculture, enhancing self-reflection and dialogue between different stakeholders should be included as one role research in this field should play. A further challenge for research is to develop and test indicators and monitor agro-ecosystem performance to feed the needs of decision-makers.

\section{Conclusion}

The assessment of functions of olive groves in the Terra Quente study area showed that these agro-ecosystems fulfil various functions. The Terra Quente area is home to a diversity of SMOPS. Traditional orchards are the most numerous and perform important ecological and social functions. Semi-intensive SMOPS have been expanding and will progressively strengthen economic functions at the regional level. They may also reveal importance for wildfire control as land under other crops is increasingly being abandoned, although a high degree of mechanisation and frequent tillage can lead to more soil erosion. A well-developed olive-oil sector may act as counterweight to ongoing emigration, and may help secure a minimum service level in rural areas. For olive orchards in process of abandonment, the lack of crop care inevitably leads to lower productivity. Minimum maintenance standards of terraces for erosion control and landscape value and of tree pruning and weeding to avoid wildfires should be established. Farmers have shown interest in agri-environmental contracts and could thus contribute to ecological functions while receiving additional income. The development of tourism should be able to reverse the trend of outmigration by contributing to employment generation (especially during summer, and hence complementary to olive growing), and maintenance of the viability of the area. Policy-makers may use function assessment as a tool to design appropriate agri-environmental subsidy schemes and crosscompliance rules that are tailored to regional agro-ecosystems and seek to achieve balanced rural development.

Carried out from a research perspective, the assessment used many different types of indicators to illustrate the current performance of these systems. Constructing houses of functions at regional and farm levels suggests that the method may have potential for application in participatory decision-making processes. Further testing and refinement is required to judge its usefulness in consensus-building and conflict resolution. However, the following preliminary conclusions can be drawn:

- The function assessment method is flexible; it can be used with either science-based (environmental) target values or subjective target values, as long as objective and relatively scaleinsensitive indicators are used.

- The function assessment method is descriptive; if objective indicators are used, the analysis can assess (differences in) performance of agro-ecosystems or suggested modifications thereof. It can also be used to show trends over time or tradeoffs between functions.

The metaphor depicted by the house of functions is applicable to all scales of analysis, but ultimately it is Oikos that cannot be substituted; multifunctionality is a luxury as much as it is a necessity - it is a matter of careful choices.

\section{Acknowledgements}

The present research has been undertaken within the framework of the EU-funded research project "The future of olive plantation systems on sloping and mountainous land; scenarios for production and natural resource conservation ("OLIVERO", contract number EU-QLK5-CT2002-01841)". The constructive criticism of two anonymous referees was highly appreciated.

\section{Appendix A. Supplementary material}

Supplementary data associated with this article can be found in the online version, at doi:10.1016/j.jrurstud.2008.08.003. 


\section{References}

Abler, D., 2001. A synthesis of country reports on jointness between commodity and non-commodity outputs in OECD agriculture. In: Workshop on Multifunctionality, Paris, 2-3 July 2001. OECD, Paris.

Agronoticias, 2005. UE / Incêndios: Portugal é o país com mais incêndios nos últimos 25 anos. <http://www.agroportal.pt/x/agronoticias/2005/01/25e.htm> (accessed 5.10.06.).

BBO, 1999. New functions, new partnerships. Searching for common ground in land use negotiations; a vision from NGO's on the multifunctional character of land and agriculture. In: Report to be Presented at the FAO Conference on the Multifunctional Character of Land and Agriculture, Maastricht, 12-17 September 1999. Bureau Beleidsvorming Ontwikkelingssamenwerking, The Hague, Netherlands.

Beaufoy, G., 2001. The Environmental Impact of Olive Oil Production in the European Union: Practical Options for Improving the Environmental Impact. European Forum on Nature Conservation and Pastoralism; Asociación para el Análisis y Reforma de la Política Agro-rural, Peterborough, UK.

Birdlife International, WWF, 2004. EU Policies for Olive Farming; Towards Sustainable Production in Europe. Birdlife International, WWF, Brussels.

Bosshard, A., 2000. A methodology and terminology of sustainability assessment and its perspectives for rural planning. Agric. Ecosyst. Environ. 77, 29-41.

Bouma, F., van der Ploeg, S.W.F., 1975. Functies van de natuur: een economischoecologische analyse. Instituut voor Milieuvraagstukken, Vrije Universiteit, Amsterdam.

Brandt, J., Vejre, H., 2004. Multifunctional landscapes - motives, concepts and perspectives. In: Brandt, J., Vejre, H. (Eds.), Multifunctional Landscapes. Theory, Values and History, vol. I. WIT Press, Southampton, Boston, pp. 3-31.

Burton, R.J.F., 2004. Reconceptualising the 'behavioural approach' in agricultural studies: a socio-psychological perspective. J. Rural Stud. 20, 359-371.

Clark, J.R.A., 2005. The 'New Associationalism' in agriculture: agro-food diversification and multifunctional production logics. J. Econ. Geogr. 5, 475-498.

Clergue, B., Amiaud, B., Pervanchon, F., Lasserre-Joulin, F., Plantureux, S., 2005. Biodiversity: function and assessment in agricultural areas. A review. Agron. Sustain. Dev. 25, 1-15.

Conway, G.R., 1987. The properties of agroecosystems. Agric. Syst. 24, 95-117.

de Figueiredo, T., Almeida, A., Araujo, J., Martelli, G.P., 2002. Edaphic characteristics of olive-tree areas in the Tras-os-Montes Region (Portugal): a map-based approach. In: Vitagliano, C. (Ed.), Proceedings of the 4th International Symposium on Olive Growing, 25-30 September 2000, Valenzano, Italy, pp. 151-154.

de Graaff, J., Eppink, L.A.A.J., 1999. Olive oil production and soil conservation in southern Spain, in relation to EU subsidy policies. Land Use Policy 16, 259-267.

de Groot, R.S., 1992. Functions of Nature: Evaluation of Nature in Environmental Planning, Management and Decision Making. Wolters-Noordhoff BV, Groningen.

de Groot, R.S., Wilson, M.A., Boumans, R.M.J., 2002. A typology for the classification, description and valuation of ecosystem functions, goods and services. Ecol. Econ. 41, 393-408.

DEASR, 2004a. Contribution to deliverable no. 7: overview of productive, ecological economic and social functions of different types of olive orchards. In: Metzidakis, I.E. (Ed.), An Overview of Productive, Ecological, and Socioeconomic Functions of SMOPS. OLIVERO Project Communication No. 2. Chania, pp. 61-77.

DEASR, 2004b. Contribution to deliverable no. 6: maps of different types of SMOPS in major production countries in southern Europe. In: Metzidakis, I.E. (Ed.) Maps of Different Types of SMOPS in Major Production Countries in Southern Europe. OLIVERO Project Communication No. 1. Chania, pp. 35-53.

DGRF, 2005. Estatísticas nacionais de incêndios florestais. Totais por Concelho (1980-2004). Direcção Geral de Recursos Florestais, Ministério da Agricultura, do Desenvolvimento Rural e das Pescas, Lisbon, Portugal. <http://www.dgrf. min-agricultura.pt/v4/dgf/pub.php?ndx=1467> (accessed 10.10.06.).

Duarte, F., Jones, N., Lúcio, C., 2004. Tipologia e funções dos sistemas de produção olivícola em Trás-os-Montes - typology and functions of olive production systems in Trás-os-Montes. In: IV Congresso Nacional de Economistas Agrícolas. APDEA, Faro.

Eicher, I., 2005. Olive Cultivation and Nature Conservation in the Rio Douro Valley: Future Options for Traditional Olive Plantation Systems on Steep Slopes in the International Douro Nature Park, Portugal. OLIVERO Student Report Series No. 5.

Evans, N., Morris, C., Winter, M., 2002. Conceptualizing agriculture: a critique of post-productivism as the new orthodoxy. Prog. Hum. Geogr. 26, 313-332.

Fleskens, L., 2005. Overview of Production Costs for Sloping and Mountainous Olive Plantation Systems (SMOPS) Under Different Circumstances. OLIVERO Working Paper No. 3. Wageningen.

Fleskens, L., de Graaff, J., 2003. Soil conservation options for olive orchards on sloping land. In: Garcia Torres, L., Benites, J., Martinez Vilela, A., HolgadoCabrera, A. (Eds.), Conservation Agriculture: Environment, Farmers Experiences, Innovations, Socio-Economy, Policy. Kluwer Academic Publishers, Dordrecht, pp. 381-385.

Fleskens, L., Stroosnijder, L., Ouessar, M., De Graaff, J., 2005. Evaluation of the on-site impact of water harvesting in southern Tunisia. J. Arid Environ. 62, 613-630.

Fuller, A.M., 1990. From part-time farming to pluriactivity: a decade of change in Rural Europe. J. Rural Stud. 6, 361-373.

Gómez-Sal, A., Belmontes, J.-A., Nicolau, J.-M., 2003. Assessing landscape values: a proposal for a multidimensional conceptual model. Ecol. Model. 168, 319-341.
Gómez, J.A., Battany, M., Renschler, C.S., Fereres, E., 2003. Evaluating the impact of soil management on soil loss in olive orchards. Soil Use Manag. 19, 127-134.

GPPAA, 2000. Portugal - Panorama Agricultura 1999. Gabinete de Planeamento e Política Agro-Alimentar, Lisbon.

GPPAA, 2002. Portugal Rural: Territórios e Dinâmicas. Gabinete de Planeamento e Pólitica Agro-Alimentar, Lisbon.

Hall, C., McVittie, A., Moran, D., 2004. What does the public want from agriculture and the countryside? A review of evidence and methods. J. Rural Stud. 20 211-225.

Harvey, D.R., 2003. Agri-environmental relationships and multi-functionality: further considerations. World Econ. 26, 705-725.

Hein, L., van Koppen, K., de Groot, R.S., van Ierland, E.C., 2006. Spatial scales, stakeholders and the valuation of ecosystem services. Ecol. Econ. 57, 209-228.

Hodge, I., 2000. Agri-environmental relationships and the choice of policy mechanism. World Econ. 23, 257-273.

Hollander, 2004. Agricultural trade liberalization, multifunctionality, and sugar in the south Florida landscape. Geoforum 35, 299-312.

Holmes, J., 2002. Diversity and change in Australia's rangelands: a post-productivis transition with a difference? Trans. Inst. Br. Geogr. 27, 362-384.

Holmes, J., 2006. Impulses towards a multifunctional transition in rural Australia: gaps in the research agenda. J. Rural Stud. 22, 142-160.

IDRHa, 2005. Produtos tradicionais com nomes protegidos; apresentação de dados sobre produção, preços e comercialização 2002. Instituto de Desenvolvimento Rural e Hidráulica, Lisbon.

INE, 2001. Recenseamento Geral da Agricultura 1999. Principais Resultados Tras-osMontes. Instituto Nacional da Estatística Portugal, Lisbon. <http://www.ine.pt $>$ (accessed 15.11.06.).

INE, 2002. Contas Économicas da Agricultura 2002. Instituto Nacional da Estatística Portugal, Lisbon. <http://www.ine.pt> (accessed 15.11.06.).

Jollands, N., 2006. How to aggregate sustainable development indicators: a proposed framework and its application. Int. J. Agric. Resour. Gov. Ecol. 5, 18-34.

Kaljonen, M., Rikkonen, P., 2004. Divergent images of multifunctional agriculture: a comparative study of the future images between farmers and agri-food experts in Finland. Int. J. Agric. Sustain. 2, 190-204.

Knickel, K., 2001. The marketing of Rhöngold milk: an example of the reconfiguration of natural relations with agricultural production and consumption. J. Environ. Pol. Plan. 3, 123-136.

Knickel, K., Renting, H., 2000. Methodological and conceptual issues in the study of multifunctionality and rural development. Sociol. Ruralis 40, 512-528.

Kuiper, J., 2000. A checklist approach to evaluate the contribution of organic farms to landscape quality. Agric. Ecosyst. Environ. 77, 143-156.

López-Ridaura, S., van Keulen, H., van Ittersum, M.K., Leffelaar, P.A., 2005. Multiscale methodological framework to derive criteria and indicators for sustainability evaluation of peasant natural resource management systems. Environ. Dev. Sustain. 7, 51-69.

Lopez Ridaura, S., 2005. Multi-scale Sustainability Evaluation: a Framework for the Derivation and Quantification of Indicators for Natural Resource Management Systems. Wageningen University and Research Centre, Wageningen, The Netherlands. Tropical Resource Management Papers 68.

Losch, B., 2004. Debating the multifunctionality of agriculture: from trade negotiations to development policies by the south. J. Agrarian Change 4, 336-360.

Madureira, L., Rebelo, J., Ferreira, P., 1994. A olivicultura e sector do azeite em Trásos-Montes e Alto Douro: situação actual e perspectivas. Universidade de Trásos-Montes e Alto Douro, Vila Real.

Madureira, L., Rambonilaza, T., Karpinski, I., 2007. Review of methods and evidence for economic valuation of agricultural non-commodity outputs and suggestions to facilitate its application to broader decisional contexts. Agric. Ecosyst Environ. 120, 5-20.

Makhzoumi, J.M., 1997. The changing role of rural landscapes: olive and carob multi-use tree plantations in the semiarid Mediterranean. Landscape Urban Plan 37, 115-122.

Margaris, N.S., Koutsidou, E., Giourga, C., 1996. Changes in traditional Mediterranean land-use systems. In: Brandt, C.J., Thornes, J.B. (Eds.), Mediterranean Desertification and Land Use. Wiley, Chichester, pp. 29-42.

Marsden, T., Murdoch, J., Lowe, P., Munton, R., Flynn, A., 1993. Constructing the countryside. UCL Press, London.

McCarthy, J., 2005. Rural geography: multifunctional rural geographies - reactionary or radical? Prog. Hum. Geogr. 29, 773-782.

MEA, 2005. Millenium Ecosystem Assessment, Ecosystems and Human Well-being: Current State and Trends. Island Press, Washington, DC.

OECD, 2001. Multifunctionality; Towards an Analytical Framework. OECD Publications, Paris.

Paarlberg, P.L., Bredahl, M., Lee, J.G., 2002. Multifunctionality and agricultural trade negotiations. Rev. Agric. Econ. 24, 322-335.

Pachaki, C., 2003. Agricultural landscape indicators: a suggested approach for the scenic value. In: NIJOS/OECD Expert Meeting - Agricultural Landscape Indicators. NIJOS Rapport 7/2003. NIJOS, Oslo, pp. 247-257.

Pacini, C., Wossink, A., Giesen, G., Vazzana, C., Huirne, R., 2003. Evaluation of sustainability of organic, integrated and conventional farming systems: a farm and field-scale analysis. Agric. Ecosyst. Environ. 95, 273-288.

Pastor, M., Castro, J., 1995. Soil management systems and erosion. Olivae 59, 64-74.

Pereira, M.G., Trigo, R.M., da Camara, C.C., Pereira, J.M.C., Leite, S.M., 2005. Synoptic patterns associated with large summer forest fires in Portugal. Agric. For. Meteorol. 129, 11-25.

Potter, C., Burney, J., 2002. Agricultural multifunctionality in the WTO - legitimate non-trade concern or disguised protectionism? J. Rural Stud. 18, 35-47. 
Pretty, J., Brett, C., Gee, D., Hine, R., Mason, C., Morison, J., Rayment, M., van der Bijl, G., Dobbs, T., 2001. Policy challenges and priorities for internalizing the externalities of modern agriculture. J. Environ. Plan. Manag. 44, 263-283.

Randall, A., 2002. Valuing the outputs of multifunctional agriculture. Eur. Rev. Agric. Econ. 29, 289-307.

Randall, A., 2007. A consistent valuation and pricing framework for non-commodity outputs: progress and prospects. Agric. Ecosyst. Environ. 120, 21-30.

Reis, J., Hespanha, P., Pires, A.R., Jacinto, R., 1990. How 'rural' is agricultural pluriactivity? J. Rural Stud. 6, 395-399.

Rodriguez, L.C., Pascual, U., Niemeyer, H.M., 2006. Local identification and valuation of ecosystem goods and services from Opuntia scrublands of Ayacucho, Peru. Ecol. Econ. 57, 30-44

Santos, M., Cabral, J.A., 2004. Development of a stochastic dynamic model for ecological indicators' prediction in changed Mediterranean agroecosystems of north-eastern Portugal. Ecol. Indicators 3, 285-303.

Siebert, S.F., 2004. Traditional agriculture and the conservation of biological diversity in Crete, Greece. Int. J. Agric. Sustain. 2, 109-117.

Slee, B., 2007. Social indicators of multifunctional rural land use: the case of forestry in the UK. Agric. Ecosyst. Environ. 120, 31-40.

Stobbelaar, D.J., Kuiper, J., van Mansvelt, J.D., Kabourakis, E., 2000. Landscape quality on organic farms in the Messara valley, Crete organic farms as components in the landscape. Agric. Ecosyst. Environ. 77, 79-93.

Stroosnijder, L., Mansinho, M.I., Palese, A.M., 2008. OLIVERO: the project analysing the future of olive production systems on sloping land. J. Environ. Manage 89, 75-85.

Tahvanainen, L., Ihalainen, M., Hietala Koivu, R., Kolehmainen, O., Tyrvainen, L. Nousiainen, I., Helenius, J., 2002. Measures of the EU Agri-Environmental Protection Scheme (GAEPS) and their impacts on the visual acceptability of Finnish agricultural landscapes. J. Environ. Manag. 66, 213-227.

Tait, J., 2001. Science, governance and multifunctionality of European agriculture. Outlook Agric. 30, 91-95.

van Cauwenbergh, N., Biala, K., Bielders, C., Brouckaert, V., Franchois, L., Garcia Cidad, V., Hermy, M., Mathijs, E., Muys, B., Reijnders, J., 2007. SAFE - a hierarchical framework for assessing the sustainability of agricultural systems. Agric. Ecosyst. Environ. 120, 229-242.

van der Maarel, E., Dauvellier, P.L., 1978. Naar een globaal ecologisch model voor de ruimtelijke ontwikkeling. Ministerie van Volkshuisvesting en Ruimtelijke Ordening, The Hague.

van der Ploeg, S.W.F., Vlijm, L., 1978. Ecological evaluation, nature conservation and land use planning with particular reference to methods used in the Netherlands. Biol. Conserv. 14, 197-221.

van der Werf, H.M.G., Petit, J., 2002. Evaluation of the environmental impact of agriculture at the farm level: a comparison and analysis of 12 indicator-based methods. Agric. Ecosyst. Environ. 93, 131-145.

Vatn, A., 2002. Multifunctional agriculture: some consequences for international trade regimes. Eur. Rev. Agric. Econ. 29, 309-327.

von Wiren-Lehr, S., 2001. Sustainability in agriculture - an evaluation of principal goal-oriented concepts to close the gap between theory and practice. Agric. Ecosyst. Environ. 84, 115-129.

Wilson, G.A., 2001. From productivism to post-productivism and back again? Exploring the (un)changed natural and mental landscapes of European agriculture. Trans. Inst. Br. Geogr. 26, 77-102.

Wilson, G.A., 2007. Multifunctional Agriculture: a Transition Theory Perspective. CABI, Wallingford, UK.

Wilson, G.A., Buller, H., 2001. The use of socio-economic and environmental indicators in assessing the effectiveness of EU agri-environmental policy. Eur. Environ. 11, 297-313.

Wortmann, C.S., Christiansen, A.P., Glewen, K.L., Hejny, T.A., Mulliken, J., Peterson, J.M., Varner, D.L., Wortmann, S., Zoubek, G.L., 2005. Farmer research: conventional experiences and guidelines for alternative agriculture and multi-functional agro-ecosystems. Renew. Agric. Food Syst. 20, 243-251.

Zalidis, G., Stamatiadis, S., Takavakoglou, V., Eskridge, K., Misopolinos, N., 2002. Impacts of agricultural practices on soil and water quality in the Mediterranean region and proposed assessment methodology. Agric. Ecosyst. Environ. 88, 137-146. 